\title{
THE DETERMINANTS OF FINANCIAL PERFORMANCE OF SMALL AND MEDIUM SCALE ENTERPRISES IN BADULLA DISTRICT
}

\author{
Nalika K.M. Jeewanthia ${ }^{a}$ T. Bhavan ${ }^{\frac{\Omega}{b}}$ \\ ${ }^{a}$ Department of Commerce, Faculty of Commerce and Management, \\ Eastern University, Sri Lanka \\ ${ }^{b}$ Department of Commerce, Faculty of Commerce and Management, \\ Eastern University, Sri Lanka
}

\begin{abstract}
Small and Medium Enterprises are backbone of the economic growth in all countries. SMEs make up a large part of Sri Lanka's economy as well. There is limited information related to the relationship between socio-economic factors and the financial performance of small and medium scale enterprises in Badulla district. Therefore, the objective of this study is to attempt to investigate how for the determinants as socioeconomic factors influencing on the financial performance of small and medium scale enterprises in Badulla district. Simple random sampling method was applied to select 100 SMEs in Badulla district. The data were collected using structured questionnaires. Univariate and multiple regression analysis were employed in data analysis. Extents of the influence of Socio-Economic factors on SMEs were measured using two groups of variables Social and Economic factors such as Access to Infrastructure, Support of Family Members, Availability of Managerial Experience, Business Information Services (Social factors) and Access to Finance, Government Policy and Regulations, Macro-Economic Indicators (Economic factors). The results suggest that Social factors are found to have high influence on the performance compared to the Economic factors on the performance of small and medium scale enterprises in Badulla District. As personal factors, Age of the owner, investment level, experience and marital status of the owner are also having influence on the performance of SMEs Badulla District. It is recommended that the government should have attention to improve IT skills of SMEs owners because, of lack of IT skills of owners. To develop SMEs and improve their managerial skills, government should implement granting credit facilities, entrepreneurship training programs, counseling services and research and development in a spread and regular basis for Badulla District SMEs.
\end{abstract}

Keywords: Badulla District, Financial Performance, Small and Medium Scale Enterprises, Socio - Economic factors

\section{Introduction}

\section{Background of the Study}

Small and Medium Enterprises (SMEs) can be recognized as important propeller of economic growth, productivity, innovation and employment, and are accepted as major aspect of economic dynamism. The absolute issue of performance in the small and medium enterprise is the transforming ideas into economic opportunities. History shows that economic progress has been significantly advanced by utilized people who are entrepreneurial and innovative, able to exploit opportunities and willing to obtain risks. Small and Medium Enterprises (SMEs) form the backbone of emerging economies and are a major source of income for most people in urban and rural communities as well. SMEs are the main source of employment in developed and developing countries. SMEs face lots of problems, that affect their growth and profitability and, hence, reduce their capability to contribute effectively to sustainable development. These problems include lack of access to credit, inadequate managerial and technical skills, low levels of education, poor market information, and lack of access to 
technology. Infrastructure as it relates to provision of access roads, adequate power, water, sewerage and telecommunication has been a major constraint in the development of Small and Medium Scale Enterprises. Small and medium enterprises play significant role in employment and income generation, producing import substituting products, mitigating ruralurban drift and mobilization of local resources (Turyahebwa and S sekajugo 2013).

SME's are integral part of economic development. SME's mostly consolidate the businesses from the informal sector into the formalized economy, hence a driving force not only for economic growth, but also poverty reduction through job creation. SME sector operates in the areas of agriculture, fishing, manufacturing, construction, whole and retail trade and repairs, hotels and restaurants, transport and storage and communications, real estate, renting and business activities, education, health and social work and other services.

The successful performance of the SME sector is dependent on a number of factors including the factors related to the entrepreneurs themselves, support facilities of the government and other organizations, socio factors, economic factors and distributed by this sector and other forces beyond the control of SMEs. Some suggestions are advanced for the SMEs underperformance such as poor access to finances and generally lack of strategic resources. Indeed, SMEs managed by owners with little knowledge in business management could suffer from this predicament.

The Federation of Chambers of Commerce and industries of Sri Lanka (FCCISL) is continuously playing major part to provide a wide range of services for the SMEs to be competitive, socially responsible and environmentally friendly and conducting a program called "Enterprise Sri Lanka? is commenced to provide support services to SMEs. Many government and private organizations are conducting development programs for SMEs in the form of training, funding, marketing and infrastructure facilities.
Small and medium-sized enterprises (SMEs) are a backbone of Sri Lankan economy, is expected to play a greater role in the development of economy. Successive governments in Sri Lanka have taken various steps towards developing the SME sector by improving access to finance, technology support, more access to information, support for skills development, better infrastructure, SME networking opportunities, linkage formation, improvement of advisory services and business development drives to support the growth of the SME sector (Yogendrarajah et al., 2017).

Badulla district is situated in the eastern part of the central hills of Sri Lanka's and it can be described as an area with separate geographical features. It is about 811,758 populations in Badulla district and there are 4927 of SMEs in Badulla district (Source - Local Government Institutes, 2016). It is included Mining and Quarrying (833), Food - beverages and tobacco (1534), Textile - wearing - apparel and leather (469), wood production and furniture (328), Paper products and printing (98), Chemicals petroleum rubber and plastic (17), Nonmetallic mineral products (64), Basic metal industries metal products - machinery and equipment (300), Other manufacturing industries (1245), Water works and supply (39) as SMEs in Badulla District.

As the successful performance of the enterprises of SMEs determine the development of the whole economy. Therefore, this study has been designed to identify the factors influencing the successful performance of the SMEs in Badulla District. Therefore, major objective of this study is to identify, how socio and economic factors influencing for the performance of the Small and Medium Scale Enterprises in Badulla district. SMEs in Badulla District are collapsing recently (Ubesiri and Gunaratne, 2015). Therefore, this research is very much important investigating whether socio and economic factors affecting on the performance of SMEs in Badulla District. There can be seen that they may face to negative impacts or constraints during their business life. However, this study is useful to identify those kinds of negative impacts on 
successful performance of SMEs in Badulla District. Because their profit and growth have been limited and less developed in SMEs and, it is not generating high income to the economy too.

There is limited information related to the relationship between socio-economic factors and the financial performance of small and medium scale enterprises in Badulla district. Therefore, the objective of this study is to attempt to investigate how for the determinants as socio-economic factors influencing on the financial performance of small and medium scale enterprises in Badulla district.

\section{Literature Review}

\section{Small and Medium Scale Enterprises in Sri Lanka}

Different countries use different kind of definitions to interpret the SME based on the development level of the country. Annual turnover, total number of employees and total investment can be used as common measures to define what SME is. According to (Ministry of Industry and commerce n.d.) SME can be defined as in Sri Lanka, the annual turnover not exceeding Rs.750 Mn and, if the number of employees less than 300 employees is called SME. In terms of definition, both conditions should be reflected in the definition of SME. SMEs are very much important strategic sector in Sri Lanka. That's to say, SMEs contributes of progress of growth and social development in the economy, fulfilling major roles such as; increasing employment, poverty alleviation, income generation and regional development (see for instant White paper 2002). (Jagoda, et al. 2008)

SMEs include organizations engaged in agriculture, mining, manufacturing, construction and service industries. However, due to lack of information, it is impossible to estimate its relative importance in the national economy (Central bank of Sri Lanka 2012). However, for SMEs, the existing database is more reliable, so it is possible to give some information on the size of the department on the basis of comparison. Although Sri Lanka's small and medium-sized enterprises were estimated to have contributed $40 \%$ of GDP between 2010 and 2012, the potential negative impact of the high borrowing of small and medium-sized enterprises on GDP growth is huge. Sometimes, high borrowing is the result of rapid business growth. Due to high borrowing, Sri Lanka's economy grew by $8 \%$ and $8.2 \%$ in 2010 and 2011, respectively, the highest GDP growth rate in the past three decades. During this period, loans to small and medium enterprises in 2011 increased by 68.3\% (Central bank of Sri Lanka 2012). This growth in borrowing requires equity support to ensure that growth is sustainable, but this is not the case in Sri Lanka. Due to high borrowings, Sri Lanka's SME growth record lags behind during 2010-2011.

According to the survey of Sri Lankan enterprises, the growth rate of SMEs in Sri Lanka is $2.9 \%$, which is very low compared to the world's $5.2 \%$ growth rate. Many surveys of SMEs show that in the first year of starting a business, a large percentage of new businesses have closed down. This shows that these companies cannot maintain their environmental status or have never achieved it. Therefore, it is clear that even if business owners start their business with the best intentions and work hard for a long time, some businesses can survive, while others fail. Industry surveys have not been conducted recently to determine the strengths, weaknesses, threats and opportunities of SMEs. The Census Department of the Ministry of Finance and Planning is conducting an annual industrial survey, but it does not cover companies that employ fewer than five people. Under this restriction, the most recent industrial survey can be traced back to 1997 . According to the annual industrial survey (1998) conducted by the Sri Lanka Census and Statistics Department, most institutions are from small businesses, but they contribute to the economy is very low (about 6\%). On the other hand, large institutions account for only $2 \%$, and their contribution is much higher, accounting for more than $50 \%$ of output. Therefore, it is obvious that although Sri Lanka has a large number of small and medium-sized enterprises, their contribution to the output and 
employment share of the national economy is very low (Amaradiwakara $U$ and Gunatilake M. 2016). (Selvamalar and Sohail M. 2006) studied twelve characteristics of female entrepreneurs. They considered women entrepreneurs in northeastern Sri Lanka. Special inspections of women entrepreneurs affected by the war. They pointed out in the survey results that a high level of demand for achievement, a high degree of self-confidence, a high degree of determination, and the desire to overcome obstacles and solve problems, and set clear goals, are the characteristics of strong female entrepreneurs who successfully start a business. Another study identified six main factors (effective management, marketing strategy, customer orientation, supportive environment, capital accessibility and product quality), which are considered to be the main contributors to the subsequent growth of Sri Lankan manufacturing SMEs (Wijewardena \& Zoysa 1993). They mainly considered small and medium-sized entrepreneurs who set up business in the greater Colombo area. In addition to these two research articles; the ILO has issued a series of working papers on small and medium-sized entrepreneurs in Sri Lanka. Wijewardena, et. al 2004) determined the degree of planning and control process and its relationship with the financial performance of manufacturing SMEs. This was done by examining the budget and budget control procedures and operational performance of 168 manufacturing SMEs operating in the Greater Colombo area of Sri Lanka. Their research shows that the complexity of planning and control is an important factor in the sales performance of manufacturing SMEs. Essentially, the results of this study show that the more complex the planning and control process, the higher the sales growth. (Pushpanathan and Lin 2008) discussed the personal entrepreneurial characteristics of the leader (owner) of a family small business. Three factors achievement, planning, and power are analyzed from the policies, procedures, and regulations of 375 small entrepreneurs. It will explain that environmental factors industrial technology, family and non-family-controlled companies, the stage of company development and company size may strengthen or weaken the link between leadership style and organizational performance. The researchers further elaborate on these background factors below.

\section{Social Factors Affecting the Performance of SMEs}

Social factors are defined as the facts and experiences that influence individuals' personality, attitudes and lifestyle. Social factors affect the market strategies put in place by a business, whether big or small. In this regard, social factors are critical components that must be considered in creating an SME operation, and growth strategy. The aspects of consumers, buyers, sellers must all be considered in determining how to hinge off a business owners SME competitive advantage. For most SME operations, business operation factors such as values, customs, and lifestyles that characterize a society, social attitudes, family size and roles, and status in the society (Gachuhi,2016).

\section{Social Attitude}

Attitude refers to how a person looks at or perceives certain situations. One's attitude towards a business is largely dependent on culture. Attitude affects a person's value system as well as shaping thoughts, actions and perceptions.

\section{Sociological Theory}

The sociological theory of entrepreneurship holds social cultures as the driving force of entrepreneurship. The entrepreneur becomes a role performer in conformity with the role expectations of the society, and such role expectations base on religious beliefs, taboos, and customs as the major driver of entrepreneurship, and stressed on the spirit of capitalism, which highlights economic freedom and private enterprise. (Kamunge et al., 2014).

\section{Education and Language}

A community is educated, and sophisticated, the more SME skills are churned out, the higher the rates business assimilations. The ability to communicate well, that is the spoken language within the community to which the SME 
operates enhances the advertising and promotion message transcription, compared to SME's cumbered with language barriers (Gachuhi, 2016) .Education and skills are needed to run micro and small enterprises observe that those with more education and training are more likely to be successful in the SME sector Gathii and Ngura, 2015).

\section{Access to Public Infrastructure}

Access to infrastructure and services such as electricity, water, serviceable roads, all critical for SMEs performance is included public infrastructure. Access to public infrastructure and services has a strong relationship with SME growth and performance Gachuhi,2016). The infrastructure problem includes poor state of roads, inaccessibility to land, work space, electricity and utility. Lack of allocation of suitable land to SMEs in most urban and rural areas is a major impediment to growth and development.

\section{Reference Group and Family}

According to reference groups and families do influence who influence the operations of SME's and growth of SME's. Reference groups do consist of people who share same values and who compare to each other as a bench mark. Family members, friends, and coworkers are good example forms of reference groups

\section{Managerial Training and Experience}

Good management need for proper planning, control, organizing skills and proper staffing with qualified and competent employees. Many SMEs owners or managers lack managerial training and experience. Although this attitude is the key strength at the start-up stage of the enterprise because it provides the creativity needed, it may present problems when complex decisions have to be made. A consequence of poor managerial ability is that SMEs owners are ill prepared to face changes in the business environment and to plan appropriate changes in technology.

Access to business information services and performance of SMEs
In developed countries, because of welldeveloped information and communication technologies (ICTs) infrastructure and easy access to computer hardware and software, SMEs enjoy easy access to business information services. In developing economies there are many challenges regarding ICTs infrastructure and the cost of IT hardware and software. This in itself has created many problems in the area of business information services for the SMEs sector. (Kamunge et al., 2014). The competitiveness of SMEs will be increased through adopting Information and Communication Technology. SMEs which have technological innovation have a higher growth compared to the SMEs which are not creative in the sales turnover, investment and job (Moorthy et al.,2012)

\section{Economic Factors Affecting Performance of SME's}

Economic factors are a set of fundamental information that affects a business or an investment's value.

\section{Access to Finance}

There are various financial challenges that face small enterprises. They include the high cost of credit, high bank charges and fees. The problem related to finance includes lack of information on where to source for finance, restrictive lending offered by commercial banks, lack of access to finance, insufficient financing, lack of track record required by the banks, limited access to collateral, and the fact that financial institutions lack appropriate structure for dealing with SMEs. Insufficient financing is as much a problem as lack of finance and as a result of scarcity of finance, small enterprises are unable to expand, modernize or meet urgent orders from customers.

\section{Government regulations}

The government regulation about wages, taxation, licensing and others are among the important reasons why the informal sector business develops. Without careful attention, government policies could crush the small business sector in any economy (Kamunge et al., 2014). 


\section{Organizational Performance}

Organizational performance refers to how well an organization achieves its market-oriented goals as well as its financial goals. Organizational performance means attainment of ultimate objectives of the organization as set out in the strategic plan. The concept of organizational performance is based upon the idea that an organization is the voluntary association of productive assets, including human, physical, and capital resources, for the purpose of achieving a shared purpose.

\section{Performance of SMEs}

Administrative problems have been cited as a major cause of business failure. It is found that poor record keeping, and lack of basic business management experience and skills were major contributors. Other factors identified are inexperience in the field of business particularly lack of technical knowledge, lack of managerial skills, inadequate planning and failure to do market research. And the performance of SMEs concludes that access to business information services affected the performance of business to a great extent and that access to finance affected performance of
SMEs because it limited the entrepreneurs' ability to take advantage of opportunity as and when they arose. Management always attempt to maximize their owner's wealth of the organization or business through maximizing the value of their shareholders (Jagoda, et al. 2008).

\section{Conceptualization}

\section{Conceptualization}

Conceptualization is the process of taking a construct or concept and refining it by giving it a conceptual or theoretical definition. The conceptualization phase of a project occurs in the initial design activity when the scope of the project is drafted and a list of the desired design features and requirements is created. According to educational researcher Smyth (2004), conceptual frameworks are structured from a set of broad ideas and theories that help a researcher to properly identify the problem they are looking at, frame their questions and find suitable literature. Figure 01 shows the conceptual framework and the framework developed by the researcher for this study.

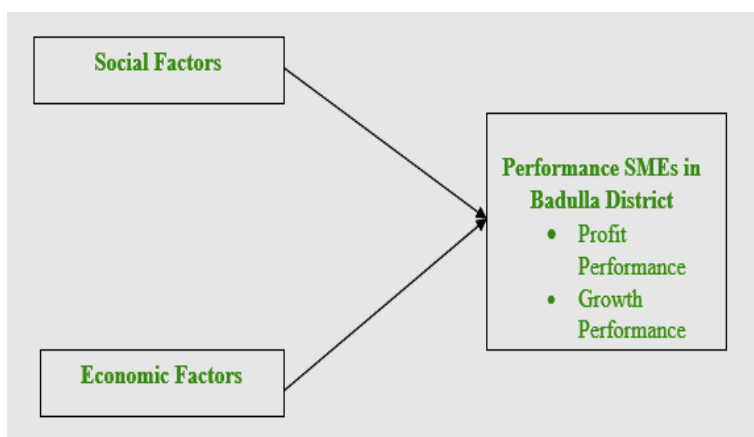

Figure 01: Conceptual Framework

Source: Developed by the Researcher

\section{Conceptualization of Socio Factors}

Socio factors such as access to infrastructure, support of family members, availability of managerial experience, success to business information services and also demographic characteristics have the ability to influence how a business generates profits, or losses, or growth.

Conceptualization of Access to Infrastructure
Favorable physical infrastructure is a factor of satisfactory performance in a small and medium scale enterprise. It includes electricity, telecommunication, water and road or transportation etc. Inadequate infrastructure makes an unsatisfied performance of SMEs. Poor telecommunication, lack of water and electricity, poor road and transportation facilities cause to small and medium scale businesses negatively. Without favorable infrastructure, SMEs face lots of difficulties for 
gaining profitable income. Limited access to public infrastructure services is a major constraint to SME survival and growth as it limits operations and restricts access to markets and raw materials.

\section{Conceptualization of Support of Family Members}

Family background is important to the entrepreneur. Support of the family members is a major role for successful performance of a small and medium scale enterprise. According to (Massis et al 2012) the agency literature suggests that family ownership may be beneficial to an SME's performance mainly because of concentrated ownership. Family ownership reduces agency costs in SMEs through facilitating monitoring of managers and discouraging managerial opportunism, up to the point to which the lack of external scrutiny engenders lack of self-control (Schulze et al. 2001) and favors myopic risk aversion and nepotism.

\section{Conceptualization of Availability of Managerial Experience}

Management is an important role in an enterprise and it helps to pursue organizational goals. Many SMEs owners or managers lack managerial training and experience. The typical owner or managers of small businesses develop their own approach to management, through a process of trial and error. As a result, their management style is likely to be more intuitive than analytical, more concerned with day-today operations than long-term issues, and more opportunistic than strategic in its concept (Hill 1987). A consequence of poor managerial ability is that SME owners are ill prepared to face changes in the business environment and to plan appropriate changes in technology (Gathii \& Ngura). Managerial experience is directly influence on the performance of the enterprises.

Conceptualization of Success to business information services

Education and also information technology knowledge are needed to run a small and medium scale enterprises. Education and training are more successful skills for an enterprise's owner. The entrepreneurs with larger stocks of human capital, in terms of education is better placed to adapt their enterprises to constantly changing business environments. SMEs are poor in usage of IT knowledge because of their poor knowledge in IT. According to updating of new technology, it is difficult to face current society enterprises' environment easily. Lack of IT knowledge and education cause to growth and profit of small and medium scale enterprises.

\section{Conceptualization of Demographic Characteristics}

SMEs are closely tied with demographical characteristics such as gender, marital status, age etc. Those are affected the preferences and attitudes towards the performance of small and medium scale enterprises. Marital status is also an important factor for the performance of SMEs. According to the (Ikeobi \& Arinze, 2016) single people are more likely to take risks than married people because they are less likely to have dependents and responsibilities.

Increasing age is strongly and positively correlated with work experience, fostering the development of entrepreneurial skills until diminishing effort associated with old age sets. Starting too late may mean the lack of the energy and resilience of youth that the business so needs. Successful entrepreneurs have the optimism and energy of youth and experience that comes with age. Women have been associated with lower levels of human capital and have had fewer opportunities to develop relevant experience and consequently have greater difficulty in assembling resources.

\section{Conceptualization of Economic Factors}

Economic factors as those factors that influences changes in costs of products, prices of products, wage rates, interest rates, and inflation. These factors have the ability to influence how a business generates profits, or losses, or growth.

\section{Conceptualization of Interest rate}

Low interest rates facilitate access to capital and thus resources required for the small and medium scale enterprises. For the investments it is needy thing to attention on interest rates in the financial environment. Loan facilities are 
provided by the financial institutions through collecting some interest gaining. Higher interest rates cause to the small business's investment level directly. It effects on the performance of small and medium scale enterprises.

\section{Conceptualization of Investment level}

According to personal worth, personal savings, loans, gaining from family members or friends offers SMEs' owners conduct their investment level. It depends on their personality or other factors such as the social behavior of the owner etc. When borrowing a loan from a bank or any other financial institution, it is key factor that interest rate. According to higher interest rates SMEs owners can't reach for loans and they face difficulties in discovering financial resources to fulfill their enterprises' needs and the initials. Investment level effects on the performance of small and medium scale enterprises.

\section{Conceptualization of Exchange rate}

Exchange rate is also considerable factor in small businesses. SMEs have to gain technical equipment, row materials from the foreign countries such as China and Japan specially. If it explains furthermore, most probably some small and medium scale enterprises are export industries. Because of these reasons Small and medium scale enterprises owners have to attention on the exchange rate definitely. As the exchange rate cause on the performance of small and medium scale enterprises, that to say it causes on the profit and the growth of the enterprise.

\section{Conceptualization of Inflation}

Inflation causes a rise in general price making goods and services expensive to the common market targeted by SME businesses. When the countries inflation levels rise, this possess a great challenge to SME owners since they are the ones who have to increase the prices to match up the high cost of production, or acquisition of raw materials. Therefore, economists and governments must always seek mechanisms to keep inflation rates lower. Inflation's effects on an economy are various and can be simultaneously positive and negative. Inflation has an effect on SMEs.

Inflation means that value of wealth decreases, consumers tighten their belts and thus there are fewer opportunities for entrepreneurs. Other negative effects of inflation include an increase in the opportunity cost of holding money, uncertainty over future inflation which may discourage investment and savings, and if inflation were rapid enough, shortages of goods as consumers begin hoarding out of concern that prices will increase in the future. Positive effects include ensuring that central banks can adjust real interest rates, and encouraging investment in non-monetary capital projects. Inflation has a negative influence on most cases to SMEs and that means that most of them have to leave the market after short time of operation.

\section{Conceptualization of Access to finance}

The availability of appropriate economic resources is important for business development. The lack of capital and limited access to finance is a factor inhibiting entrepreneurship and influencing growth negatively, as it impedes the progress that comes from timeous application of resources. Lack of finance access cause to profit and growth of a small and medium scale enterprises. The (Fouad, 2013) also indicate that, SME, financial resources are often limited. This often forces company to select a solution, which appear to be cheap initially. However, the hidden costs will start to emerge during implementation. This sometime causes the project to be abandoned or sometime sent the company into further financial crisis. As rural and poor persons, they suffer from difficulties of financing their operations of their enterprises. According to (S.Gamage, 2003) economic factors as those factors that influences changes in costs of products, prices of products, wage rates, interest rates, and inflation. These factors have the ability to influence how a business generates profits, or losses, or growth.

\section{Conceptualization of Government Regulations}

A new tax incentive regime has been introduced with the budget 2012 to promote 
private investments, both domestic and foreign. These new incentives are applicable also small and medium enterprises under the Section 16C of the Inland Revenue Act (Ministry of finance and planning 2011). Some may argue that Sri Lanka had to grant generous incentives in the past because of the poor investment climate that existed on account of the armed conflict and now that the war is over we can do away with generous incentives. However, the security situation of a country is not the only factor that would impact an investor's decision to locate of small business (Wijesinha, 2013). Ease of licensing is also a favorable regulation of government. It is better to start and conduct small businesses for rural persons as well as poor knowledgeable persons.

\section{Business performance}

companies have many possibilities for evaluating business performance. The first and also the simplest method is to evaluate the performance by one selected indicator, which is based on the company's goal. This method has pros and cons and because of them it is used by small and medium

companies. Finding ideal concept for managing and measuring business performance is a complex problem and also experts represented by consulting firms, business managers or academics has been leading various discussions about it. These include sales growth, asset growth, return on net worth.

\section{Methodology}

\section{Data}

Survey was conducted through a questionnaire in the selected SMEs and around 100 SMEs owners in that firms. Secondary data were collected from literature surveys based on various published and unpublished research, journals, books, and newspaper articles.

Table 01: SMEs by D.S. Division 2016

\begin{tabular}{|c|c|c|c|c|}
\hline No & D.S. Division & No of SMEs & Percentage & Sample size \\
\hline 1 & Rideemaliyadda & 740 & 15.02 & 15 \\
\hline 2 & Meegahakiwula & 382 & 7.75 & 8 \\
\hline 3 & Kandaketiya & 173 & 3.51 & 3 \\
\hline 4 & Soranathota & 10 & 0.20 & 1 \\
\hline 5 & Passara & 41 & 0.83 & 1 \\
\hline 6 & Lunugala & 232 & 4.71 & 5 \\
\hline 7 & Badulla & 1225 & 24.86 & 25 \\
\hline 8 & Haliela & 1101 & 22.35 & 22 \\
\hline 9 & Uva-Paranagama & 24 & 0.49 & 1 \\
\hline 10 & Welimada & 190 & 3.86 & 4 \\
\hline 11 & Bandarawela & 326 & 6.62 & 6 \\
\hline 12 & Ella & 79 & 1.60 & 2 \\
\hline 13 & Haputhale & 114 & 2.31 & 5 \\
\hline 14 & Haldummulla & 231 & 4.69 & 1 \\
\hline 15 & Mahiyanganaya & 59 & 1.20 & 100 \\
\hline & Total & 4927 & 100 & \\
\hline
\end{tabular}

Source - Local Government Institutes

\section{Population and sample Size}

The target population of this study comprised of 4927 registered SMEs operating in Badulla 
district, (Sources; Local Government Institute, Badulla 2016). The unit of analysis in this study is a single organization. A sample of 100 small and medium enterprises was randomly selected from Badura District. There are several alternative methods to select samples. Generally, these methods can be divided into two types: probabilistic techniques and nonprobabilistic techniques. This study uses probability sampling method. Based on probability sampling method, there are mainly four sampling techniques: simple random sampling, systematic sampling, stratified sampling and cluster sampling. In this study, stratified sampling was considered the most appropriate.

\section{Methods of Measurements}

The scale for statements in the questionnaire,

\begin{tabular}{|c|c|}
\hline Standard Value & Weight \\
\hline Strongly Disagree & 1 \\
\hline Disagree & 2 \\
\hline Moderate & 3 \\
\hline Agree & 4 \\
\hline Strongly Agree & 5 \\
\hline
\end{tabular}

\section{Decision Criteria}

The decision rule for level of Socio-Economic Factors influenced can be formulated as follows.

\begin{tabular}{|c|c|}
\hline Range & Decision attributes \\
\hline $01 \leq \mathrm{X} \leq 2.5$ & Low level of Socio-Economic Factors influenced \\
\hline $2.5<\mathrm{X} \leq 3.5$ & Moderate level of Socio-Economic Factors influenced \\
\hline $3.5<\mathrm{X} \leq 5.0$ & High level of Socio-Economic Factors influenced \\
\hline
\end{tabular}

\section{Multiple Regression Analysis}

Multiple regression analysis used to determine the most influencing independent variables on dependent variable. Multiple linear regression is an extension of simple Linear regression in which there is a single dependent variable and independent variables. Research regression

\section{Likert Scale Analysis}

The variables in the research model were measured through questionnaires with fivepoint Likert Scales, Nominal and Scale which were completed by the respondents themselves appropriately as they perceived respond to each and every question.

The questionnaire contained 23 statements to measure the influence of socio-economic factors on the performance of SMEs under the dimensions as mentioned in third chapter.

A five-point scale is used to measure the variables and this scale consists of five boxes ranging from very low to very high. In addition, the questionnaires are administered among the respondents to remark $(\sqrt{ })$ their options regarding the statement in questionnaire. The numerical values are given for the purpose of quantification of variable as follows; 
Y - Business Performance

Infra - Access to infrastructure

Fam - Support of family members

Exp - availability of managerial experience

Info - Business information services

Fina - Access to finance

Gov - Government policy \& regulations

Eco - Macroeconomic indicators

$\epsilon$-Error term
The bivariate analysis, the multiple regression analysis was made to find out the relationship between the dependent variable and the independent variable.

\section{Reliability Test}

The inter item consistency reliability was examined with Cronbach's Alpha test. The results of Cronbach's alpha test are given in the Table 02, which suggest that the internal reliability of each instrument is satisfactory.

\section{Data Presentation and Analysis}

Table 02: Cronbach's Alpha Coefficients

\begin{tabular}{|c|c|}
\hline Instruments & Cronbach's Alpha \\
\hline Social Factors & 0.924 \\
\hline Economic Factors & 0.890 \\
\hline Financial Performance & 0.783 \\
\hline
\end{tabular}

Source: Survey data

The content reliability of the instrument was ensured by the conceptualization and operationalization of the variables based on literature, and indirectly by the high internal consistency reliability of the instruments as denoted by alphas.

\section{Univariate Analysis}

Under the Univariate analysis, descriptive statistics is used to analyze.

Mean and Standard deviation for Socio Economic factors
Average level is analyzed by influencing descriptive statistics of mean and standard deviation of Socio - Economic factors.

\section{Socio - Economic Factors}

\section{Social Factors}

To find out the average level of Social Factors, the Social Factors are analyzed by influencing descriptive statistics of mean and standard deviation of Social Factors.

Table 03 Mean and Standard Deviation of Social Factors

\begin{tabular}{|c|c|c|}
\hline Dimension/Indicators & Mean & $\begin{array}{c}\text { Standard } \\
\text { deviation }\end{array}$ \\
\hline Access to Infrastructure & $\mathbf{3 . 9 3}$ & $\mathbf{0 . 8 0 3}$ \\
\hline $\begin{array}{c}\text { Good road network is available around my } \\
\text { business to fulfill my business needs }\end{array}$ & 3.90 & 0.870 \\
\hline $\begin{array}{c}\text { There is sufficient electricity available in the } \\
\text { working space }\end{array}$ & 3.84 & 0.861 \\
\hline $\begin{array}{c}\text { Clean Water are available and are accessible in } \\
\text { my business place }\end{array}$ & 3.85 & 1.009 \\
\hline $\begin{array}{c}\text { Access to telecommunication services is easy at } \\
\text { my business location }\end{array}$ & 4.12 & 1.008 \\
\hline
\end{tabular}




\begin{tabular}{|c|c|c|}
\hline Support of Family Members & 3.67 & 0.768 \\
\hline $\begin{array}{c}\text { I have family support in order to develop my } \\
\text { business }\end{array}$ & 3.81 & 0.918 \\
\hline $\begin{array}{l}\text { I have house assistance to carry on my business } \\
\text { well }\end{array}$ & 3.72 & 0.889 \\
\hline $\begin{array}{l}\text { My home chores influence on my business } \\
\text { performance }\end{array}$ & 3.47 & 1.077 \\
\hline Availability of Managerial Experience & 3.78 & 0.743 \\
\hline $\begin{array}{l}\text { The number of years, I have been in business } \\
\text { influence on my business performance }\end{array}$ & 3.76 & 0.866 \\
\hline $\begin{array}{l}\text { Availability of my experience on business field } \\
\text { effects on my business }\end{array}$ & 3.81 & 0.918 \\
\hline $\begin{array}{l}\text { Training on managerial skills are required for my } \\
\text { business }\end{array}$ & 3.69 & 0.800 \\
\hline $\begin{array}{l}\text { I have got an experience as training or seminar on } \\
\text { business management skills }\end{array}$ & 3.87 & 0.971 \\
\hline Business Information Services & 3.68 & 0.717 \\
\hline $\begin{array}{l}\text { My education level has been influenced for } \\
\text { performance of my business }\end{array}$ & 3.80 & 0.853 \\
\hline $\begin{array}{c}\text { I have all the technology which needed for my } \\
\text { business carrying on }\end{array}$ & 3.75 & 0.914 \\
\hline $\begin{array}{l}\text { I have financed on my business to an expansion } \\
\text { or an investment with new technology }\end{array}$ & 3.54 & 0.869 \\
\hline $\begin{array}{l}\text { The success of my business depends on the } \\
\text { ability to get development and technology } \\
\text { advantage in my business }\end{array}$ & 3.62 & 0.908 \\
\hline Overall Social Factors & 3.76 & 0.638 \\
\hline
\end{tabular}

According to the Table 03, average level of Social Factors is 3.76 and it can vary by 0.638 . Based on mean value of Social Factors, Social Factors of the Small and Medium Enterprises in Badulla district is High level. And also, other all social factors, except influencing home chores on business performance is in high- level.

\section{Economic Factors}

To find out the average level of Economic Factors, the Economic Factors are analyzed by influencing descriptive statistics of mean and standard deviation of Economic Factors.

Table 04 Mean and Standard Deviation of Economic Factors

\begin{tabular}{|c|c|c|}
\hline Dimension/Indicators & Mean & $\begin{array}{c}\text { Standard } \\
\text { Deviation }\end{array}$ \\
\hline Access to Finance & $\mathbf{3 . 5 5}$ & $\mathbf{0 . 7 6 9}$ \\
\hline $\begin{array}{c}\text { Accessibility to capital exposes my } \\
\text { business to better opportunities }\end{array}$ & 3.43 & 0.998 \\
\hline $\begin{array}{c}\text { Accessibility to capital has led to improve } \\
\text { my business performance }\end{array}$ & 3.67 & 0.933 \\
\hline $\begin{array}{c}\text { Accessibility to capital for my business is } \\
\text { very challenging }\end{array}$ & 3.56 & 0.857 \\
\hline $\begin{array}{c}\text { Government Policy and Regulations } \\
\text { There any governmental law restrictions } \\
\text { that influence in the growth of my business }\end{array}$ & $\mathbf{3 . 6 4}$ & $\mathbf{0 . 8 1 5}$ \\
\hline
\end{tabular}




\begin{tabular}{|c|c|c|}
\hline $\begin{array}{c}\text { Tax incentives are affected for my business } \\
\text { performance }\end{array}$ & 3.59 & 1.026 \\
\hline $\begin{array}{c}\text { Government Assistance in ease of licensing } \\
\text { is very crucial to promote the growth of my } \\
\text { business }\end{array}$ & 3.62 & 1.062 \\
\hline $\begin{array}{c}\text { Macro-Economic Indicators } \\
\text { ( } \begin{array}{c}\text { my business } \\
\text { Changing in interest rate directly effects on }\end{array}\end{array}$ & 3.73 & 0.897 \\
\hline $\begin{array}{c}\text { Fluctuation in exchange rate effects on my } \\
\text { business }\end{array}$ & 3.92 & 0.861 \\
\hline $\begin{array}{c}\text { Fluctuations in inflation effects on my } \\
\text { business }\end{array}$ & 3.83 & $\mathbf{3 . 8 3}$ \\
\hline Economic Factors & $\mathbf{3 . 6 7}$ & $\mathbf{0 . 6 8 5}$ \\
\hline
\end{tabular}

According to the Table 04, average level of Economic Factors is 3.67 and it can vary by 0.685. Based on mean value of Economic Factors, Economic Factors of the Small and Medium Enterprises in Badulla district is High level. And except accessibility to capital exposes the business to better opportunities, other all Economic factors are in high level.

\section{Financial Performance}

To find out the average level of financial performance, financial performance is analyzed by influencing descriptive statistics of mean and standard deviation of financial performance.

As shown in the Table 05, average level of both growth and profit (financial performance) of the small and medium enterprises in Badulla district is in High level. Because of the mean value of financial performance is 3.84 and it can vary by 0.752 .

Table 05: Mean and Standard Deviation of Financial Performance

\begin{tabular}{|c|c|c|}
\hline $\begin{array}{c}\text { Dimension/ } \\
\text { Indicator }\end{array}$ & Mean & $\begin{array}{c}\text { Standard } \\
\text { Deviation }\end{array}$ \\
\hline Growth & $\mathbf{3 . 8 9}$ & $\mathbf{0 . 7 5 8}$ \\
\hline Sales growth & 3.90 & 0.870 \\
\hline Assets growth & 3.84 & 0.861 \\
\hline Profit & $\mathbf{3 . 8 4}$ & $\mathbf{0 . 8 4 9}$ \\
\hline $\begin{array}{c}\text { Return on Net } \\
\text { worth }\end{array}$ & 3.81 & 0.918 \\
\hline $\begin{array}{c}\text { Level of } \\
\text { Financial } \\
\text { Performance }\end{array}$ & $\mathbf{3 . 8 4}$ & $\mathbf{0 . 7 5 2}$ \\
\hline
\end{tabular}

\section{Cross Tabulation Analysis}

Cross tabulation is used to comparing the mean value of Socio - Economic factors with the categorical variable of gender, education level, type of industry and marital status of the owners.
Mean comparison between Numerical Factors and Socio-Economic Factors and Financial Performance

Socio - Economic factors include major two variables, namely Social factors and Economic factors. All the two variables compare with the demographic factors of the small and medium business owners as follows. Mean comparison between Gender and socio - economic factors 
Table 06 Mean comparison of Gender and level of socio - economic factors

\begin{tabular}{|c|c|c|c|c|}
\hline \multicolumn{2}{|c|}{$\begin{array}{c}\text { Gender of the } \\
\text { Owner }\end{array}$} & Social factors & Economic factors & $\begin{array}{c}\text { Socio Economic } \\
\text { factors }\end{array}$ \\
\hline \multirow{2}{*}{ Male } & Mean & $\mathbf{3 . 7 3}$ & $\mathbf{3 . 6 2}$ & $\mathbf{3 . 6 7}$ \\
\cline { 2 - 5 } & $\begin{array}{c}\text { Std. } \\
\text { Deviation }\end{array}$ & 0.688 & 0.720 & 0.664 \\
\hline Female & Mean & $\mathbf{3 . 8 3}$ & $\mathbf{3 . 7 8}$ & $\mathbf{3 . 8 1}$ \\
\cline { 2 - 5 } & $\begin{array}{c}\text { Std. } \\
\text { Deviation }\end{array}$ & 0.524 & 0.603 & 0.526 \\
\hline Total & $\begin{array}{c}\text { Mean } \\
\end{array}$ & $\mathbf{3 . 7 6}$ & $\mathbf{3 . 6 7}$ & $\mathbf{3 . 7 2}$ \\
\cline { 2 - 5 } & $\begin{array}{c}\text { Std. } \\
\text { Deviation }\end{array}$ & 0.638 & 0.685 & 0.623 \\
\hline
\end{tabular}

Source: Survey data

Table 06 indicates that females in the sample are influencing greater level of Social factors (3.83) than males in the sample (3.73). And also influence level of both Economic factors and Socio - Economic factors are in higher among the female owners $(3.78,3.81)$ than male owners $(3.62,3.67)$.

Mean comparison between Educational Level and of Socio - Economic factors

Table 07 Mean comparison of Education Level and Socio - Economic Factors

\begin{tabular}{|c|c|c|c|c|}
\hline \multirow{2}{*}{ Education Level of the Owner } & Social factors & Economic factors & $\begin{array}{c}\text { Socio Economic } \\
\text { factors }\end{array}$ \\
\hline Below GCE O/L & Mean & $\mathbf{3 . 8 2}$ & $\mathbf{3 . 6 5}$ & $\mathbf{3 . 7 3}$ \\
\cline { 2 - 5 } & $\begin{array}{c}\text { Std. } \\
\text { Deviation }\end{array}$ & 0.506 & 0.659 & 0.539 \\
\hline \multirow{2}{*}{ GCE O/L } & Mean & $\mathbf{3 . 7 7}$ & $\mathbf{3 . 7 7}$ & $\mathbf{3 . 7 7}$ \\
\cline { 2 - 5 } & $\begin{array}{c}\text { Std. } \\
\text { Deviation }\end{array}$ & 0.593 & 0.563 & 0.475 \\
\hline \multirow{2}{*}{ Any other } & Mean & $\mathbf{3 . 9 5}$ & $\mathbf{3 . 8 5}$ & $\mathbf{3 . 9 0}$ \\
\cline { 2 - 5 } & $\begin{array}{c}\text { Std. } \\
\text { Deviation }\end{array}$ & 0.375 & 0.521 & 0.414 \\
\hline Mean & $\mathbf{3 . 6 1}$ & $\mathbf{3 . 5 3}$ & $\mathbf{3 . 5 7}$ \\
\cline { 2 - 5 } Never Attended & $\begin{array}{c}\text { Std. } \\
\text { Deviation }\end{array}$ & 0.722 & 0.806 & 0.730 \\
\cline { 2 - 5 } & $\begin{array}{c}\text { Mean } \\
\text { Std. }\end{array}$ & $\mathbf{3 . 5 5}$ & $\mathbf{3 . 4 8}$ & $\mathbf{3 . 5 1}$ \\
\hline Teviation & Mean & $\mathbf{3 . 7 6}$ & $\mathbf{3 . 6 7}$ & $\mathbf{3 . 7 2}$ \\
\hline & $\begin{array}{c}\text { Std. } \\
\text { Deviation }\end{array}$ & 0.638 & 0.685 & 0.623 \\
\hline
\end{tabular}

As shown in Table 07, business owners who are educated GCE A/L influence high level of 
Socio - Economic factors (3.90) than other educational levels. And SMEs owners of educated GCE A/L influence high level of Socio - Economic factors for other both social factors and economic factors. Business owners of the sample who are educated up to below GCE O/L, GCE O/L, any other diploma/degree and never attended are influencing Socio - Economic factors with the mean value of $3.73,3.77,3.57$ and 3.51 respectively.

Mean comparison between business characteristics and Socio - Economic factors Socio - Economic factors include two variables, namely Social factors and Economic factors. All the two variables compare with the business characteristics of the small and medium businesses as follows.

Table 08 Mean comparison of Type of the Industry and Socio - Economic Factors

\begin{tabular}{|c|c|c|c|c|}
\hline \multicolumn{2}{|c|}{ Type of the Industry } & $\begin{array}{l}\text { Social } \\
\text { factors }\end{array}$ & Economic & Socio-Economic \\
\hline \multirow[b]{2}{*}{ Manufacturing } & Mean & 3.71 & 3.83 & 3.77 \\
\hline & $\begin{array}{c}\text { Std. } \\
\text { Deviation }\end{array}$ & 0.683 & 0.622 & 0.607 \\
\hline \multirow{2}{*}{$\begin{array}{c}\text { Beverage food \& } \\
\text { Tobacco }\end{array}$} & Mean & 3.82 & 3.78 & 3.8 \\
\hline & $\begin{array}{c}\text { Std. } \\
\text { Deviation }\end{array}$ & 0.212 & 0.429 & 0.27 \\
\hline \multirow[b]{2}{*}{ Textiles and foot wear } & Mean & 3.74 & 3.45 & 3.59 \\
\hline & $\begin{array}{c}\text { Std. } \\
\text { Deviation }\end{array}$ & 0.814 & 0.874 & 0.784 \\
\hline \multirow[b]{2}{*}{ Hotels and travel } & Mean & 3.88 & 3.77 & 3.82 \\
\hline & $\begin{array}{c}\text { Std. } \\
\text { Deviation }\end{array}$ & 0.593 & 0.405 & 0.447 \\
\hline \multirow[b]{2}{*}{ Services } & Mean & 3.52 & 3.34 & 3.43 \\
\hline & $\begin{array}{c}\text { Std. } \\
\text { Deviation }\end{array}$ & 0.817 & 0.944 & 0.868 \\
\hline \multirow{2}{*}{$\begin{array}{c}\text { Paper products and } \\
\text { printing }\end{array}$} & Mean & 3.86 & 3.9 & 3.88 \\
\hline & $\begin{array}{c}\text { Std. } \\
\text { Deviation }\end{array}$ & 0.392 & 0.296 & 0.322 \\
\hline \multirow[b]{2}{*}{ Others } & Mean & 3.85 & 3.75 & 3.8 \\
\hline & $\begin{array}{c}\text { Std. } \\
\text { Deviation }\end{array}$ & 0.622 & 0.723 & 0.66 \\
\hline \multirow[b]{2}{*}{ Total } & Mean & 3.76 & 3.67 & 3.72 \\
\hline & $\begin{array}{c}\text { Std. } \\
\text { Deviation }\end{array}$ & 0.638 & 0.685 & 0.623 \\
\hline
\end{tabular}

Source: Survey data

Table 08 indicates that, Paper products and printing SMEs high level of Socio - Economic factors (3.88) than other industry. Service industry of the sample is using lower level of Socio - Economic factors (3.43) than Paper products and printing industry and beverage food and tobacco, Textiles and foot wear, hotels and travels and other industries having mean value with $3.80,3.59,3.82$, and 3.80 respectively for Socio - Economic factors. 
Mean comparison between Marital Status and Socio - Economic factors

Table 09 Mean comparison of Marital Status and level of Socio - Economic factors

\begin{tabular}{|c|c|c|c|c|}
\hline \multicolumn{2}{|c|}{ Gender of the Owner } & Social factors & Economic factors & $\begin{array}{l}\text { Socio Economic } \\
\text { factors }\end{array}$ \\
\hline \multirow[t]{2}{*}{ Married } & Mean & 3.83 & 3.73 & 3.78 \\
\hline & $\begin{array}{c}\text { Std. } \\
\text { Deviation }\end{array}$ & 0.604 & 0.655 & 0.609 \\
\hline \multirow[t]{2}{*}{ Single } & Mean & 3.73 & 3.64 & 3.68 \\
\hline & $\begin{array}{c}\text { Std. } \\
\text { Deviation }\end{array}$ & 0.656 & 0.704 & 0.632 \\
\hline \multirow[t]{2}{*}{ Total } & Mean & 3.76 & 3.67 & 3.72 \\
\hline & $\begin{array}{c}\text { Std. } \\
\text { Deviation }\end{array}$ & 6.38 & 0.685 & 0.623 \\
\hline
\end{tabular}

\section{Source: Survey data}

Table 09 mentions that the married owners in the sample are influencing greater level of Social factors (3.83) than single owners in the sample (3.73). And also influence levels of both Economic factors and overall socio economic factors are in higher among the married owners $(3.73,3.78)$ than single owners of SMEs in Badulla district. (3.64, 3.68).

\section{Bivariate Analysis}

The Bivariate analysis includes multiple regression analysis, which is used to investigate to identify the relationship between independent and dependent variable. Hence, this analysis related to final objectives of the research.

\section{Regression Analysis}

As a multivariate analysis, the multiple regression analysis is in order to investigate the simultaneously impacts of all the independent variable on the dependent variable. The result of regression of the two independent variables (social factors and economic factors) and dependent variable of financial performance are presented in the Table 10.

Table 10: Influence of the independent predictors on financial performance of SMEs

\begin{tabular}{|c|c|c|c|c|}
\hline \multirow[t]{2}{*}{ Variables } & \multicolumn{2}{|c|}{ Growth Model } & \multicolumn{2}{|c|}{ Profit Model } \\
\hline & & $\mathrm{t}$ & & $\mathrm{t}$ \\
\hline Socio Factors & $\begin{array}{c}.806 * * * \\
(.000)\end{array}$ & 5.839 & $\begin{array}{c}.652 * * * \\
(.000)\end{array}$ & 5.598 \\
\hline Economics Factors & $\begin{array}{c}-.197 * * \\
(.097)\end{array}$ & -1.681 & $\begin{array}{l}-.077 \\
(.430)\end{array}$ & -.792 \\
\hline Dummy gender & $\begin{array}{l}-.054 \\
(.629)\end{array}$ & -.485 & $\begin{array}{l}-.034 \\
(.709)\end{array}$ & -.374 \\
\hline Age Level (Years) & $\begin{array}{l}.008 \\
(.403)\end{array}$ & .841 & $\begin{array}{c}.024 * * * \\
(.005)\end{array}$ & 2.911 \\
\hline Below $\mathrm{O} / \mathrm{L}$ & $\begin{array}{l}-.015 \\
(.922)\end{array}$ & -.098 & & \\
\hline
\end{tabular}




\begin{tabular}{|c|c|c|c|c|}
\hline $\mathrm{O} / \mathrm{L}$ & $\begin{array}{c}.189 \\
(.233)\end{array}$ & 1.201 & & \\
\hline Degree/Diploma & $\begin{array}{l}-.239 * \\
(.139)\end{array}$ & -1.495 & & \\
\hline No attended & $\begin{array}{l}-.051 \\
(.729)\end{array}$ & -.348 & & \\
\hline Level of investment & $\begin{array}{l}6.619 * \\
(.164)\end{array}$ & 1.405 & $\begin{array}{c}3.266 * * * \\
(.000)\end{array}$ & 8.381 \\
\hline Manufacturing & $\begin{array}{l}.318 * * \\
(.080)\end{array}$ & 1.776 & $\begin{array}{l}-.013 \\
(.929)\end{array}$ & -.089 \\
\hline Beverage food and tobacco & $\begin{array}{l}.350 * * \\
(.060)\end{array}$ & 1.909 & $\begin{array}{l}.225^{*} \\
(.140)\end{array}$ & 1.490 \\
\hline Hotels.and.travel & $\begin{array}{l}.264 * \\
(.157)\end{array}$ & 1.430 & $\begin{array}{c}.043 \\
(.786)\end{array}$ & .272 \\
\hline Services & $\begin{array}{l}.435 * * \\
(.021)\end{array}$ & 2.351 & $\begin{array}{c}.053 \\
(.729)\end{array}$ & .348 \\
\hline Paper product and printing & $\begin{array}{c}.085 \\
(.659) \\
\end{array}$ & .443 & $\begin{array}{l}-.094 \\
(.543)\end{array}$ & -.611 \\
\hline Other & $\begin{array}{l}.285 * * \\
(.098)\end{array}$ & 1.673 & $\begin{array}{c}.001 \\
(.993)\end{array}$ & .009 \\
\hline Experience & $\begin{array}{l}.035 * * \\
(.087)\end{array}$ & 1.734 & $\begin{array}{l}-.011 \\
(.498) \\
\end{array}$ & -.680 \\
\hline marital status & $\begin{array}{l}.212 * * \\
(.045)\end{array}$ & 2.034 & $\begin{array}{l}-.025 \\
(.772)\end{array}$ & -.290 \\
\hline Size of the family & $\begin{array}{l}-.075^{*} \\
(.107)\end{array}$ & -1.630 & $\begin{array}{l}-.051 * \\
(.167)\end{array}$ & $\begin{array}{c}- \\
1.392\end{array}$ \\
\hline (Constant) & $\begin{array}{c}.551 \\
(.211)\end{array}$ & 1.260 & $\begin{array}{l}-.286 \\
(.413)\end{array}$ & -.823 \\
\hline F stat & 10.120 & & 26.784 & \\
\hline $\mathbf{R}^{2}$ & .692 & & .815 & \\
\hline
\end{tabular}

Source; Survey Data*, ** and *** indicate the level of significant at 10\%, 5\%, 1\%, respectively.

With reference to the above Table 10, independent variables (predictors) are Social factors and economic factors. The result shows that the p-values are less than 0.05 for social factors, services and marital status as respectively $0.000,0.021$ and 0.045 . Social factors show 0.000 of significant value. And Social factors have a strongly significant at the level of significant of $1 \%$ impact on the Growth of SMEs owners in Badulla district.

And also, the result shows that the p-values are less than 0.05 for social factors, Investment level and the marital status as respectively $0.000,0.000$ and 0.045 . Social factors and Investment level show 0.000 of significant values. And Social factors, age and Investment level have a strongly significant at the level of significant of $1 \%$ impact on the Profit of SMEs owners in Badulla district.

The highest $t$ values are for Growth model are included in social factors (5.839), age of the owner (2.911), investment level (1.405), manufacturing (1.776), beverage food and tobacco (1.909), hotel and travel (1.430), services (2.351), other industries (1.673), 
experience of the owner (1.734) and marital status of SME owner (2.034).

The highest $t$ values are for Profit model are included in social factors (5.598), Age of the owner (2.911), investment level (8.381) and beverage food and tobacco industry (1.490).

The square of the multiple $\mathrm{R}$ is 0.692 , which indicates that $69.2 \%$ of the variation in Growth is explained by all independent variables mentioned above. Therefore, the model is adequate as $\mathrm{R}^{2}$ is more than $50 \%$. The $\mathrm{F}$ value is 10.120 , which is significantly at $5 \%$ ( $\mathrm{Sig}=$ 0.05), which suggests that the two variables have significantly explained $69.2 \%$ of the variance in the Growth. The strength of the influence that each of the independent variable had on the dependent variable (Growth) are determined by the use of multiple regression coefficients of the independent variable.

The square of the multiple $\mathrm{R}$ is 0.815 , which indicates that $81.5 \%$ of the variation in Profit is explained by all independent variables mentioned above. Therefore, the model is adequate as $\mathrm{R}^{2}$ is more than $50 \%$. The $\mathrm{F}$ value is 10.120 , which is significantly at $5 \%$ ( $\mathrm{Sig}=$ 0.05), which suggests that the two variables have significantly explained $81.5 \%$ of the variance in the Profit. The strength of the influence that each of the independent variable had on the dependent variable (Profit) were determined by the use of multiple regression coefficients of the independent variables.

There is a positive relationship between both the growth and the profit of the small and medium enterprises in Badulla district and the socio factors. It is a strong positive relationship. But Economic factors influence on business performance of SMEs in Badulla district negatively. Under the economic factors there are three dimensions as access to finance, government policy and regulations and Macro Economic indicators. Especially, interest rates, inflation rate and the exchange rate effect negatively on the SMEs in Badulla district. It causes on sales growth, assets growth and returns on net worth of the SMEs.

And the investment level effects positively on the performance of SMEs in Badulla district. There is a strong positive relationship between the investment level and the profit of SMEs in Badulla district according to the collected data. When the investment level is increasing, the profit and the growth of SMEs is increasing. And there is a positive relationship between experience and the growth of SMEs in Badulla district. There is a positive relationship between Age level of SMEs owners and the performance of SMEs in Badulla district.

As dummy variables such as qualitative variables of gender of the owner, education level and the marital status of owner also effects on the performance of SMEs. $Y=0.551$ $-0.54 \mathrm{~g}$ (gender). In this case female $=1$ and male $=0$. Then $\mathrm{Y}$ will be $0.011(0.554-0.54 * 1)$.

\section{Discussion}

\section{Discussion on numerical factors}

Based on the findings of the research data analysis, this part presents a discussion about numerical factors. Those eight factors are namely gender of the owner, age of the owner, education level of the owner, investment level, type of business, experience of the owner, marital status of the owner and size of the family of small business owner.

\section{Gender of business owners}

The study observes that there are many male owners than females. Out of the 100 owners' sample $67 \%$ owners are males and rest of $33 \%$ is females.

When take the variables of both social factors and economic factors for female owners have a higher mean value $(3.83,3.78)$ than the male owners $(3.73,3.62)$. Also, the overall Socio Economic factors for female owners have a higher mean value of 3.81 than the male owners (3.67). However, that indicates average influence level of Socio - Economic factors are higher among the female owners than among male owners.

\section{Educational level of business owners}

There are five educational levels included in the data. Most of the owners educated up to G.C.E. A/L (28\%) and least of them educated 
with GCE O/L and any other diploma or degree with same percentage of $16 \%$. Owners who educated below GCE O/L and never attended are respectively, $22 \%$ and $18 \%$.

When compare with educational levels of the owners, GCE A/L qualified SME owners have been influenced by socio - economic factors influencing. Also, GCE A/L qualified owners are highly influenced by socio factors and economic factors respectively with mean values are 3.95 and 3.85. Never attended owners indicate a low mean value in all social, economic and Socio - Economic factors respectively as $3.55,3.48$ and 3.51 .

\section{Type of the industry}

According to the frequency distribution, highest number of businesses in the sample is in the industry of textiles \& foot wear (18\%). However, there is no high variation in number of small and medium enterprises in each industry in the sample and lowest number of small and medium enterprises is in the industry of paper products and printing.

Average influence level of socio factors is high in the industry of hotel and travel (3.88) and average influence level both of economic factors and socio - economic factors (3.90, 3.88) are high in the industry type of paper products and printing.

\section{Marital status of the SME owner}

The study observes that there are many single owners than married SME owners. Out of the 100 owners' sample $65 \%$ owners are single and rest of $35 \%$ is married.

When take the variables of both social factors and economic factors for married owners have a higher mean value $(3.83,3.73)$ than the single owners $(3.73,3.64)$. Also, the overall socio economic factors for married owners have a higher mean value of 3.78 than the male owners (3.68). However, that indicates average influence level of socio - economic factors are higher among the married owners than among male owners.

\section{Discussions on research variables}

\section{Social factors}

$83 \%$ of small and medium enterprises from the sample are influenced high level of social factors and $10 \%$ from the sample are using moderate level of social factors. Only the 07\% from total sample is using low level social factors. That indicates in majority of the sample are using high level of social factors.

When considering the mean values of dimensions and indicators of social factors, there is high level of influencing socio factors on the performance of small and medium scale enterprises in Badulla district. Namely, access to infrastructure, support of family members, availability of managerial experience and business information services are affected in high level. Because, those are closely related factors, when SME owners involving their small business activities of SMEs owners in Badulla district.

Mean value of social factors is 3.76 and standard deviation is 0.638 . However, average level of social factors influence of small and medium enterprises in Badulla district is high level.

Based on the multiple regression analysis results p-value is 0.000 . That's to say, the social factors are influenced in highest level of significant on (both growth and profit) financial performance of SMEs owners in Badulla district.

\section{Access to Infrastructure}

$81 \%$ of small and medium enterprises from the sample are influenced high level of Access to Infrastructure and $11 \%$ from the sample are influenced moderate level of Access to Infrastructure. Only the $08 \%$ from total sample is influenced low level of Access to Infrastructure. That indicates in majority of the sample are influenced high level of Access to Infrastructure.

Mean value of Access to Infrastructure is 3.93 and standard deviation is 0.803 . However, average level of Access to Infrastructure 
influence of small and medium enterprises in Badulla district is high level.

\section{Support of Family Members}

$65 \%$ of small and medium enterprises from the sample are influenced high level of Support of Family Members and 28\% from the sample are using influenced moderate level of Support of Family Members. Only the 07\% from total sample is influenced low level of Support of Family Members. That indicates in majority of the sample are influenced high level of Support of Family Members.

Mean value of Support of Family Members is 3.67 and standard deviation is 0.768 . However, average level of Support of Family Members influence of small and medium enterprises in Badulla district is high level.

\section{Availability of Managerial Experience}

$75 \%$ of small and medium enterprises from the sample are influenced high level of Availability of Managerial Experience and 16\% from the sample are influenced moderate level of Availability of Managerial Experience. Only the $09 \%$ from total sample is influenced low level of Availability of Managerial Experience. That indicates in majority of the sample are influenced high level of Availability of Managerial Experience.

Mean value of Availability of Managerial Experience is 3.78 and standard deviation is 0.743 . However, average level of Availability of Managerial Experience influence of small and medium enterprises in Badulla district is high level.

\section{Business Information Services}

$59 \%$ of small and medium enterprises from the sample are influenced high level of Business Information Services and 32\% from the sample are influenced moderate level of Business Information Services. Only the 09\% from total sample is influenced low level of Business Information Services. That indicates in majority of the sample are influenced high level of Business Information Services.

Mean value of Business Information Services is 3.68 and standard deviation is 0.717 . However, average level of Business Information Services influence of small and medium enterprises in Badulla district is high level.

\section{Economic factors}

$70 \%$ of small and medium enterprises from the total sample are influenced high level economic factors and $24 \%$ is in moderate level. Only the $06 \%$ of businesses are influenced low level of economic factors. That is, only a large number of businesses are influenced economic factors in highly.

When we consider economic factors, all economic factors are highly influenced on business performance of SMEs in Badulla district. Namely, Access to Finance, Government Policy and Regulations, MacroEconomic Indicators are highly influenced as mentioned above. Because, those are closely related factors, when SME owners involving their small business activities of SMEs owners in Badulla district.

Mean value of economic factors is 3.67 and standard deviation is 0.685 . However, average level of economic factors influence of small and medium enterprises in Badulla district is high level.

According to the results of multiple regression analysis, economic factors have a negative impact on growth of SMEs with high level of significant. But in the performance of profit, economic factors are not influencing on profit of SMEs in Badulla district.

\section{Access to Finance}

$56 \%$ of small and medium enterprises from the sample are influenced high level of Access to Finance and $36 \%$ from the sample are influenced moderate level of Access to Finance. Only the $08 \%$ from total sample is influenced low level of Access to Finance. That indicates in majority of the sample are influenced high level of Access to Finance.

Mean value of Access to Finance is 3.55 and standard deviation is 0.769 . However, average level of Access to Finance influence of small and medium enterprises in Badulla district is 
high level.

\section{Government Policy and Regulations}

$68 \%$ of small and medium enterprises from the sample are influenced high level of Access to Finance and $23 \%$ from the sample are influenced moderate level of Access to Finance. Only the $09 \%$ from total sample is using low level of Access to Finance. That indicates in majority of the sample are influenced high level of Access to Finance.

Mean value of Access to Finance is 3.64 and standard deviation is 0.815 . However, average level of Access to Finance influence of small and medium enterprises in Badulla district is high level.

\section{Macro-Economic Indicators}

$68 \%$ of small and medium enterprises from the sample are influenced high level of MacroEconomic Indicators and 23\% from the sample are influenced moderate level of MacroEconomic Indicators. Only the $09 \%$ from total sample is influenced low level of MacroEconomic Indicators. That indicates in majority of the sample are influenced high level of Macro-Economic Indicators.

Mean value of Macro-Economic Indicators is 3.64 and standard deviation is 0.815 . However, average level of Macro-Economic Indicators influence of small and medium enterprises in Badulla district is high level.

\section{Socio - Economic Factors}

These discussions are about the influence level of Socio - Economic Factors of small and medium business owners in Badulla district. $79 \%$ of small and medium enterprises of the sample are influenced high level of Socio Economic Factors while 15\% influenced moderate level of Socio - Economic Factors. Only $06 \%$ of the sample is influenced low level of Socio - Economic Factors. That is, majority of small and

medium enterprises of the sample are influenced high level of Socio - Economic Factors. Mean value of Socio - Economic Factors is 3.72 and standard deviation is 0.623 .
That reflects the average level of Socio Economic Factors of small and medium enterprises in Badulla district is high level.

\section{Financial Performance}

There are two dimensions of financial performance growth and profit. The mean value of the business growth is 3.89 with 0.758 standard deviation. The mean value of the business profit is 3.84with 0.849 standard deviation. Mean value of the financial performance is 3.84. According to this coefficient it can be concluded that it is at high level of financial performance. The standard deviation of financial performance of small and medium business is 0.752 . Level of financial performance of SMEs in Badulla district is high level.

\section{Conclusion}

The objective of this study was to investigate how of social and economic factors influencing on the financial performance of the Small and Medium Scale Enterprises in Badulla District. Simple random sampling method was applied to select 100 SMEs in Badulla district. Frequency analysis was used to understand the sample profile and descriptive statistics were used to investigate the extent of Socio Economic factors influencing on business performance among them. Univariate and Multiple Regression Analysis were employed in data analysis. Extents of the influence of Socio-Economic factors on SMEs were measured using two groups of variables Social and Economic factors. The results suggest that Social factors are found to have high influence on the performance compared to the Economic factors on the performance of small and medium scale enterprises in Badulla District. However, the results suggested that there is a significant relationship between determinants of socio-economic factors on

the financial performance of small and medium scale enterprises in Badulla District in Sri Lanka. Moreover, it was found that socio factors rather than economic factors significantly impact on the financial performance of SMEs in Badulla district.

\section{References}


Amaradiwakara U, A, and M. Gunatilake M. "Factors Affecting Growth of Small and Medium Enterprises in Sri Lanka." Journal of Business \& Economic Policy, 2016: 64-65.

Easterly W, and Rebelo. "Fiscal policy and economic growth: an empirical investigation." Journal of Monetary Economics, 1993: 5-30.

Edison. et al, H.J., Levine, R., Ricci, L. and Slok, T. "International financial integration and economic growth." Journal of International Money and Finance, 2002: 749-776.

Fouad, Menna Allah Ahmed. "The factors affecting the performance of small and medium enterprises in the manufacturing sector of Cairo, Egypt." Iternational Journal of Business and Management Studies 5 (2013): 160.

Gathii, Kamau John, and Mathew Mwangi Ngura. "Socio-Economic Determinants of Performance of Small and Medium Enterprises (SMEs) in Gilgil Town of Nakuru County, Kenya." IOSR Journal Of Humanities And Social Science 20, no. 8 (n.d.): 111 - 113.

Grossman, G.M, and E. Helpman. "Innovation and Growth in the Global Economy." Cambridge MA: MIT Press, 1991.

Hemachandra, W.M. "Financial Deepening and its Implications for the Sri Lankan Economy." Staff Studies by Central Bank of Sri Lanka Printing Press, 2005: 15-32.

Ikeobi, Nneka Rosemary, and Peter E. Arinze. "The Influence of Demographic Factors on the Investment Objectives of Retail Investors in the Nigerian Capital Market." European Journal of Business and Management 8 (2016): 147 - 148.

J C Berthelemy, and A. Varoudakis. "Clubs de Convergence et Croissance. Le Rôle du Développement Financier et du Capital Humain." Revue Economique, 1995.

Jagoda, K.J.M.M., et al., A.G.M.N Madadeniya, K.A.P Ravinath, W.P.M Ranaweera, and H.P.I.P Pushpakumara.
"Relationship between financial reporting and analysis practices and financial performance of small and medium enterprises (SMEs) in Sri Lanka." mgt.sjp.ac.lk/acc/wp-conten, 2008: 2-5.

Massis , Alfredo De, Josip Kotlar, Giovanna Campopiano, and Lucio Cassia. "The Impact of Family Involvement on SMEs' Performance: Theory and Evidence." n.d.: 8 - 13.

Pushpanathan A. "Factors Influencing the Organizational Performance in Small Scale Industries in Sri Lanka." 2008: 181182.

Pushpanathan, and Z. Lin. "Leader's Personal Entrepreneurial Characteristics in Family Owned Small Enterprises in Sri Lanka." International Conference, Rajiv Academy for Technology and Management, India, 2008.

R Yogendrarajah, L Kengatharan, and S Jeyan Suganya. "Financial management practices and performance of SMEs in Sri Lanka: evidence from Jaffna District." International journal of Accounting \& Business Finance, 2017: 62.

Rajan, R, J, and L, Zingales. "Financial system, industrial structure and growth." Oxford Review of Economic Policy, 2001: 467482.

S.Gamage, Aruna . "Small and medium enterprise development in Sri Lanka - A review." 2003.

Selvamalar, I., and S. Sohail M. "Profile of women entrepreneurs in a Wartorn Area: Case Study of North East Sri Lanka." School of Entrepreneurial Development, Malaysia, 2006.

Turyahebwa, Abanis, and Derick S sekajugo. "Financial management practices and business performance of small and medium enterprises in western Uganda." African journal of business management, November 2013: 3875, 3876. 
Wijesinha, Anushka. "The role of tax incentives in attracting investment to Sri Lanka." May 2013.

Wijewardena, and Zoysa. "Factor analytic study of the determinants of success in manufacturing SMEs." 1993.

Wijewardena, et al, Zoysa, and Fonsek. "The impact of planning and control sophistication on performance of small and medium-sized enterprises: Evidence from Sri Lanka." Journal of Small Business Management, 2004: 209-217. 